MICROPALAEONTOLOGY NOTEBOOK

\title{
Riedeliusella, a new name for the genus Riedelius De Wever, 1982 (Radiolaria), non Hudec, 1961 (Gastropoda)
}

\author{
PATRICK DE WEVER ${ }^{1} \&$ LUIS O'DOGHERTY ${ }^{2}$ \\ ${ }^{1}$ Muséum National d'Histoire Naturelle, Géologie, 43 Rue Buffon, F-75005 Paris, France (e-mail: pdewever@mnhn.fr) \\ ${ }^{2}$ Dept Geología, Facultad de Ciencias del Mar, Universidad de Cádiz, 11510 Puerto Real, Spain (e-mail: lodogher@uca.es)
}

De Wever (1982) proposed the new radiolarian name Riedelius from the Lower Jurassic of Turkey. It has been found that this name has already been used by Hudec in 1961 for a mollusc gastropod. Therefore, in accordance with Article 60 of the International Code of Zoological Nomenclature (1999), the name Riedeliusella nomen novum is proposed as a replacement name (type species Riedelius williami De Wever, 1982, p. 201; 1982 , by original designation) for the preoccupied homonym Riedelius De Wever, 1982, non Hudec, 1961, p. 110.

\section{REFERENCES}

De Wever, P. 1982. Nassellaria (Radiolaires Polycystines) du Lias de Turquie. Revue de Micropaléontologie, 24 (4): 189-232.

Hudec, V. 1961. K diskusi o plzi Oxychilus (Riedelius) inopinatus (Ulicny, 1887). Zur Diskussion über die Schnecke Oxychilus (Riedelius) inopinatus (Ulicny, 1887). Acta Musei Nationalis Pragae, Series B Historia Naturalis (Praha), 17: 97-128.

International Commission on Zoological Nomenclature 1999. International Code of Zoological Nomenclature, 4th edn. The International Trust for Zoological Nomenclature, London, 306pp. 